\title{
Lycorine reduces mortality of human enterovirus 71-infected mice by inhibiting virus replication
}

\author{
Jiangning Liu', Yajun Yang ${ }^{1}$, Yanfeng $\mathrm{Xu}^{2}$, Chunmei Ma ${ }^{2}$, Chuan Qin ${ }^{1,2}$ and Lianfeng Zhang ${ }^{1,2^{*}}$
}

\begin{abstract}
Human enterovirus 71 (EV71) infection causes hand, foot and mouth disease in children under 6 years old and this infection occasionally induces severe neurological complications. No vaccines or drugs are clinical available to control EV71 epidemics. In present study, we show that treatment with lycorine reduced the viral cytopathic effect (CPE) on rhabdomyosarcoma (RD) cells by inhibiting virus replication. Analysis of this inhibitory effect of lycorine on viral proteins synthesis suggests that lycorine blocks the elongation of the viral polyprotein during translation. Lycorine treatment of mice challenged with a lethal dose of EV71 resulted in reduction of mortality, clinical scores and pathological changes in the muscles of mice, which were achieved through inhibition of viral replication. When mice were infected with a moderate dose of EV71, lycorine treatment was able to protect them from paralysis. Lycorine may be a potential drug candidate for the clinical treatment of EV71-infected patients.
\end{abstract}

Keywords: Human enterovirus 71, Lycorine, Mouse model, Drug

\section{Introduction}

Human enterovirus 71 (EV71) is a positive-stranded RNA virus belonging to the enterovirus genus of the Picornaviridae family [1]. EV71 infection predominantly leads to hand, foot and mouth disease (HFMD) in children under 6 years old [2,3]. Most of the EV71 infections resolve spontaneously; however, EV71 infection occasionally causes neurological complications that can lead to cardiopulmonary failure and death [4-7]. Outbreaks of EV71 have erupted around the world in the past decades and mainly appearing in the countries and regions of Asia in recent years [8-10]. Hundreds of cases involving lethal complications have been reported in each outbreak $[2,11,12]$, and the epidemic is still prevalent in Asia [13].

Currently, there are no vaccines or antiviral drugs available to use against EV71 infection in the clinic, and the prevention of EV71 epidemics depends upon public surveillance alone. In recent years, there have been many efforts to develop drugs to combat EV71 infection and dozens of drugs have been reported to show anti-EV71 activity in vitro, some of which have been evaluated in

\footnotetext{
* Correspondence: zhanglf@cnilas.org

'Key Laboratory of Human Diseases Comparative Medicine, Ministry of Health; Institute of Laboratory Animal Science, CAMS \& Comparative Medicine Centre, PUMC, Chao Yang Strict, Pan Jia Yuan Nan Li No.5, Beijing 100021, China

Full list of author information is available at the end of the article
}

animal models including bovine lactoferrin [14], ribavirin [15], siRNA [16] and type I interferon [17]. Although these drugs showed activity against EV71 infection both in cell lines and in animal models, the clinical application is not yet available.

Lycorine is one of the most abundant alkaloids of Amaryllidaceae [18], and has a wide range of biological effects including apoptotic effects on tumor cells [19], antimalarial effects [20], anti-inflammatory effects [21] and induction of nausea and emesis [22]. Importantly, lycorine also has been shown to have antiviral effects on human immunodeficiency virus (HIV-1), severe acute respiratory syndrome-associated coronavirus (SARS$\mathrm{CoV}$ ), poliovirus, coxsackie virus, measles virus, and herpes simplex virus type 1 [23-25].

In the present study, the activity of lycorine against EV71 replication was investigated in vitro and in mice models infected with EV71 strain.

\section{Materials and methods}

\section{Cells and viruses}

Human rhabdomyosarcoma cells (RD) were maintained in Dulbecco's modified Eagle's medium (DMEM) containing $10 \%$ fetal bovine serum (FBS) as previously described [26]. A clinically isolated EV71 strain FY0805 (GenBank accession no. HQ882182) and the mouse-adapted EV71 strain 
MP10 (GenBank accession no. HQ712020) derived from FY0805 were cultured in RD cells. The virus titres were determined using a plaque assay as described [27], and working stocks of virus containing $10^{9} \mathrm{TCID}_{50} / \mathrm{ml}$ were prepared for experiments.

\section{Antiviral assay in RD cells}

For the antiviral assay, RD cells $\left(2 \times 10^{4}\right.$ cells/well $)$ were plated in 96-well plates with DMEM medium lacking antibiotics and grown overnight to $90 \%$ confluence at $37^{\circ} \mathrm{C}$. The RD cells were then infected with $100 \mathrm{TCID}_{50}$ of FY0805 and cultured continually in DMEM medium containing $2 \%$ FBS. The infected cells were treated with lycorine (purity $\geq 98 \%$ in an HPLC assay, National institutes for food and drug control) in a set of concentrations in saline as $0.1,0.5,1,2,5,10$ and $20 \mu \mathrm{g} / \mathrm{ml}$. The infected RD cells were observed for CPE or harvested at eight-hour intervals post infection to determine the number of viral RNA copies by quantitative RT-PCR (qRT-PCR). The half maximal inhibitory concentration $\left(\mathrm{IC}_{50}\right)$ was defined as the concentration of lycorine that caused a 50\% CPE reduction compared to that of the saline-treated control [14].

\section{Cytotoxicity Assay}

The concentration of lycorine that was required for $50 \%$ cell cytotoxicity $\left(\mathrm{CC}_{50}\right)$ was determined in RD cells as described previously [28]. Briefly, RD cells were plated in 96-well plates and grown overnight to $90 \%$ confluence at $37^{\circ} \mathrm{C}$. The cells were then treated with lycorine for 72 hours at $37^{\circ} \mathrm{C}$ in a set of concentrations between 1 and $200 \mu \mathrm{g} / \mathrm{ml} \mathrm{CC}_{50}$ was defined as the concentration of lycorine that caused 50\% CPE of RD cells.

\section{Viral proteins expression assay by western blotting}

To assess the expression of viral proteins following lycorine treatment, RD cells $\left(2 \times 10^{4}\right.$ cells/well $)$ were plated in 96-well plates and grown overnight to $90 \%$ confluence at $37^{\circ} \mathrm{C}$. The cells were then infected with $10^{5} \mathrm{TCID}_{50}$ of FY0805 and cultured continually for 6 hours. The infected cells were treated with $1 \mu \mathrm{g} / \mathrm{ml}$ lycorine. The infected RD cells were harvested after washing three times with PBS (pH 7.2, Gibco) at 0.5, 1.0 and 1.5 hours of treatment. The harvested cells were resuspended in $20 \mu \mathrm{l}$ of PBS and lysed with three freeze-thaw cycles and the cell debris was then removed by centrifugation at 3,000 g for 20 minutes. The supernatants were subjected to viral RNA and protein analysis, and the infected RD cells treated with saline were used as control.

For western blotting assay, equal amounts of aliquots (20 $\mu$ l of supernatants) were separated by $12 \%$ SDSPAGE and transferred onto a nitrocellulose membrane (Immobilon NC, Millipore France). The polyclonal mouse antibodies against the viral peptides were prepared in our lab (anti- $\mathrm{P}_{70-159}$ for VP2, anti- $\mathrm{P}_{324-443}$ for VP3, anti- $\mathrm{P}_{566-665}$ for VP1, anti- $\mathrm{P}_{1329-1440}$ for $2 \mathrm{C}$, anti$\mathrm{P}_{1649-1731}$ for $3 \mathrm{C}$, and anti- $\mathrm{P}_{1843-1951}$ for $3 \mathrm{D}, 1: 1000$ dilution) [29]. Primary antibodies were visualised with HRP-conjugated goat anti-mouse secondary antibodies (Sigma) using a chemiluminescent detection system (Santa Cruz). The bands were quantified by densitometry using Quantity One software. The intensity of bands for six viral proteins in the saline-treated group were used as standards and defined as 100 . The density of the bands of viral proteins in the lycorine-treated group was compared to their respective standards.

\section{Determination of the viral load}

qRT-PCR was used to detect the viral RNA copy number. Briefly, total RNA was isolated from cultured cells or tissues from mice using the TRIzol reagent. The total RNA was then reverse transcribed using random hexamers with a reverse-transcription kit (Promega). The cDNA was subjected to quantitative PCR (QuantiTect SYBR Green RT-PCR kit, QIAGEN) with a Roche Light Cycler3.5 system for 40 cycles. The primers were EV71S1 (5'-AGATAGGGTGGCAGATGTAATTGAAAG-3') and EV71-A1 (5' - TAGCATTTGATGATGCTCCAAT TTCAG-3'). A fragment corresponding to nucleotides 2462-2635 of FY0805 was adjusted to a concentration gradient $\left(1 \times 10^{1}\right.$ copies $/ \mu \mathrm{l}$ to $1 \times 10^{8}$ copies $\left./ \mu \mathrm{l}\right)$ and was used as standard to calculate the copy number of viral RNA. Results were normalised to GAPDH.

Semi-quantitative RT-PCR was used to confirm the results of qRT-PCR. Briefly, the viral cDNA obtained above was assayed by PCR amplification with the same primers, and the results were normalised to GAPDH.

\section{Mouse protection assay}

Ten- or eleven-day-old ICR mice were provided by the Institute of Laboratory Animal Science, Peking Union Medical College. All of the animal protocols were approved by the institutional animal care and use committee. For lethal EV71 challenge, each ten-day-old mouse was intraperitoneally (i.p.) inoculated with $1 \times 10^{7} \mathrm{TCID}_{50}$ (lethal dose) of MP10. For self-limited model development, each mouse at eleven-day-old was inoculated with 1 $\times 10^{6} \mathrm{TCID}_{50}$ of MP10 via the i.p. route. At 12 hours post infection, the infected mice were intraperitoneally injected with different concentrations of lycorine in saline daily twice for 7 days. The placebo group was injected with the same volume of saline as control. The symptoms and survival rates of infected mice were monitored daily for 2 weeks, the clinical scores were graded following previously described standards [15] and the muscle tissues of mice were sampled at $1 \mathrm{dpi}, 3 \mathrm{dpi}, 5 \mathrm{dpi}, 7 \mathrm{dpi}$ and $9 \mathrm{dpi}$ and sent for virology and pathology analysis. 


\section{Pathology}

For each experimental group, six mice were subjected to pathologic examination. After euthanasia, the muscle tissues were immediately immersion-fixed in $10 \%$ buffered formalin for 48 hours. The tissues were bisected, embedded in paraffin, and stained with hematoxylin and eosin stain (H\&E). Ten sections of muscle were observed per animal in a blinded manner.

\section{Immunohistochemistry}

Immunohistochemistry (IHC) was used to detect virions in the infected tissues as described previously [26]. Briefly, the sections were incubated with a monoclonal mouse antibody for VP1 of EV71 (Millipore, 1:200 dilution) for 1 hour at $37^{\circ} \mathrm{C}$. The sections were then washed three times with PBS and incubated with HRP-conjugated goat anti-mouse IgG (1:5000 dilution, Sigma) for 1 hour at $37^{\circ} \mathrm{C}$. The sections were developed with 3-3'diaminobenzidine (DAB) and observed under a light microscope (Olympus).

\section{Statistics}

All data are expressed as the mean \pm SD. The statistical significance of differences in mean values was assessed by Duncan's multiple-range test following a one-way analysis of variance (ANOVA), and survival rates were analysed by Kaplan-Meier analysis. A P value of $<0.05$ was considered to be significant.

\section{Results}

Lycorine inhibits EV71 infection in RD cells

The anti-EV71 efficacy of lycorine was tested on a human muscular (RD) cell line in a plaque reduction assay. As a positive control, the $\mathrm{IC}_{50}$ of ribavirin was

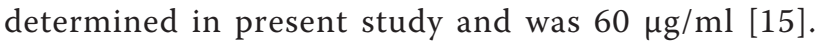
Similarly, lycorine inhibited EV71 infection of RD cells in a dose-dependent manner with an $\mathrm{IC}_{50}$ of $0.48 \mu \mathrm{g} / \mathrm{ml}$ (Figure 1A). And the replication of EV71 (Figure 1B) and majorities of the CPE in RD cells (Figure 1C) were significantly inhibited by treatment with $1.0 \mu \mathrm{g} / \mathrm{ml}$ lycorine. The $\mathrm{CC}_{50}$ of lycorine $(48.5 \mu \mathrm{g} / \mathrm{ml}$, Figure 2$)$ on $\mathrm{RD}$
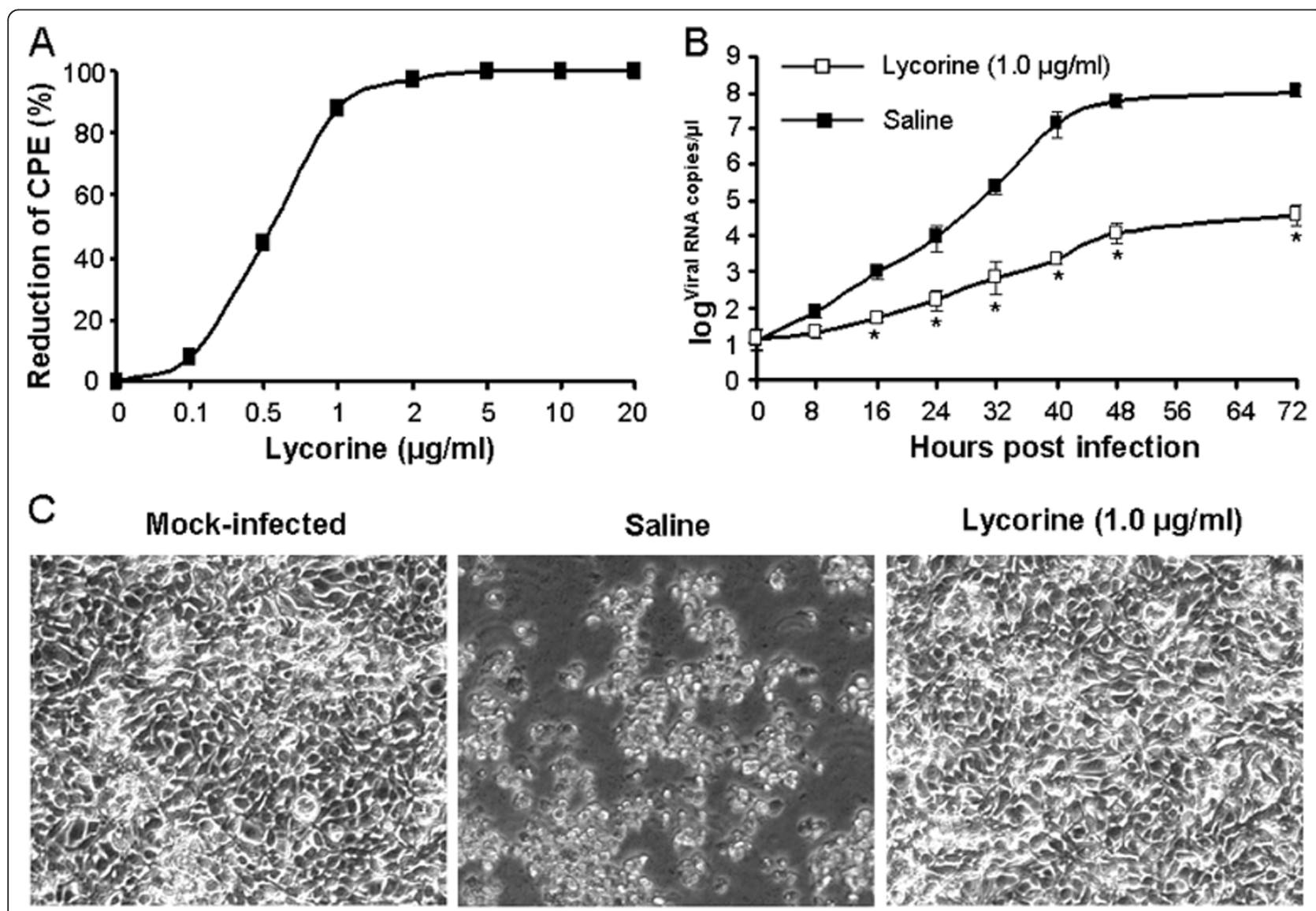

Figure 1 The inhibition effect of lycorine on RD cells. A, IC 50 of lycorine for inhibiting EV71 infection was determined by the reduction of CPE on RD cells. B, the viral copy number was detected by GRT-PCR in the RD cells treated with lycorine at a dose of $1 \mu \mathrm{g} / \mathrm{ml}$. The data are expressed as mean values of three independent experiments $\pm S D, *: p<0.05$. C, CPE of EV71-infected RD cells at 3 dpi were observed under light microscope (100x). 


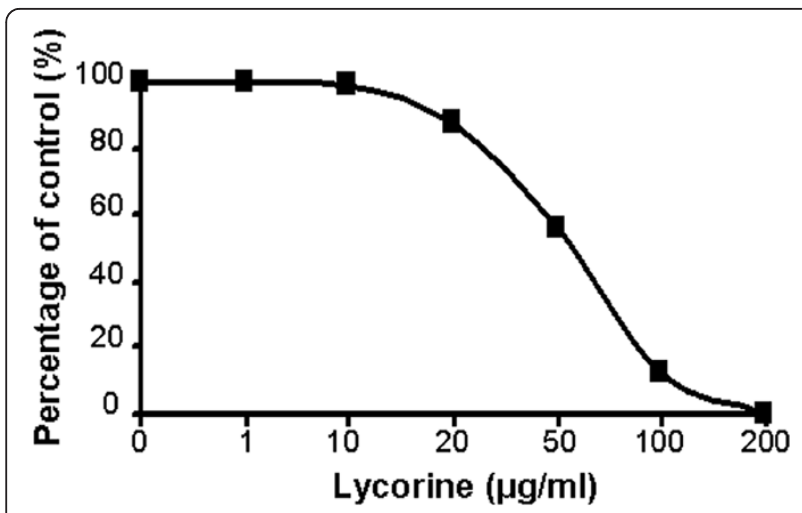

Figure 2 Determination of the $\mathrm{CC}_{50}$ of lycorine on RD cells. The RD cells were seeded into the 96-well plate and culture for 24 hours. Lycorine with different concentrations were added in the wells and cultured continually for 3 days. The $\mathrm{CC}_{50}$ was calculated by the CPE of RD cells. The data are expressed as mean values of three independent experiments.

cells was approximately 100 -fold higher than the $\mathrm{IC}_{50}$ of it against EV71 infection.

\section{Lycorine blocked the elongation of the viral polyprotein} during translation

To study the inhibitory mechanism of lycorine against EV71 infection, the synthesis of several typical viral proteins were detected by western blotting in 1.5 hours periods following lycorine treatment, when the effects of inhibition was just appeared (Figure 3A and 3B). VP2, VP3, VP1, 2C, 3C and 3D were sequentially translated from $\mathrm{N}$-terminal to $\mathrm{C}$-terminal of the viral polyprotein during viral proteins synthesis. The band densities of these proteins at 1.0 hour of saline-treatment were set as 100 . Then the densities of these proteins at 1.0 hour of lycorine-treatment were compared with that of saline-treatment respectively (Figure $3 \mathrm{~B}$ and $3 \mathrm{C}$ ). The inhibition of lycorine on synthesis of $\mathrm{C}$ terminal proteins was more remarkable than that of $\mathrm{N}$ terminal proteins, as the inhibitory rate of VP2 was $12.7 \%$, whereas that of 3D was $66.5 \%$. This result suggested that lycorine affected the elongation of the viral polyprotein during translation.

\section{Lycorine reduced the mortality of mice upon lethal EV71 challenge}

We utilized the mouse model of lethal EV71 infection to evaluate the effect of lycorine on inhibiting EV71 infection. The placebo-treated mice developed paralysis at $3 \mathrm{dpi}$ and all of them died within $10 \mathrm{dpi}$, and treatment with ribavirin $(50 \mathrm{mg} / \mathrm{kg}$ body weight) enhanced the survival rate of infected-mice to $12 \%$. Meanwhile, the lycorine-treatment at doses of $0.1 \mathrm{mg} / \mathrm{kg}$ prolonged the survival time of mice; while the treatment at doses of 0.4 or $1.0 \mathrm{mg} / \mathrm{kg}$ enhanced the survival rates of mice to $45 \%$ respectively (Figure $4 \mathrm{~A}$ ).

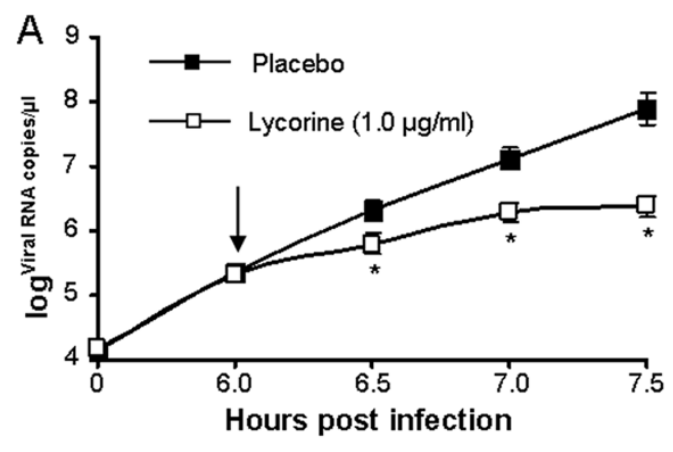

B
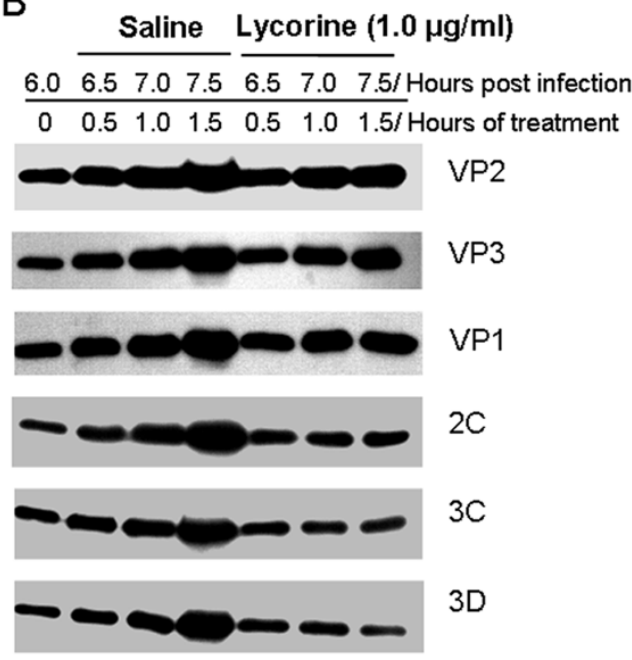

C

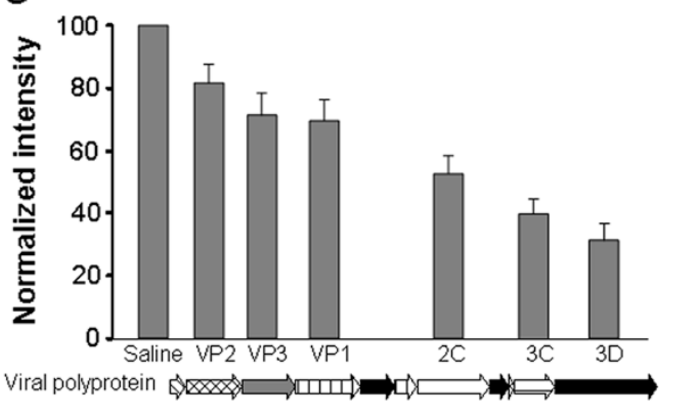

1.0 hour of lycorine treatment (7.0 hours post infection)

Figure 3 Lycorine inhibited the elongation of EV71 polyprotein. The RD cells were cultured in 96-well plate and infected with EV71 virus. The cells were treated with or without lycorine $(1 \mu \mathrm{g} / \mathrm{ml})$ at 6 hours post infection. A, the Viral RNA copies in RD cells were determined by qRT-PCR in a 0.5 hour intervals for 1.5 hours of treatment and the early stage of lycorine inhibition for virus was detected (*: $p<0.05$ ); $B$, in the early stage of virus inhibition (0.5, 1.0 and 1.5 hours of lycorine treatment), the amounts of viral proteins in infected RD cells was detected by western blotting with the specific primary antibodies against different viral proteins. C, the intensity of bands of viral proteins in control cells were defined as 100, and the intensity of bands of viral proteins in lycorine-treated cells were compared respectively with those of saline-treated cells at 1 hour of treatment. These data are expressed as mean values of three independent experiments \pm SD. 

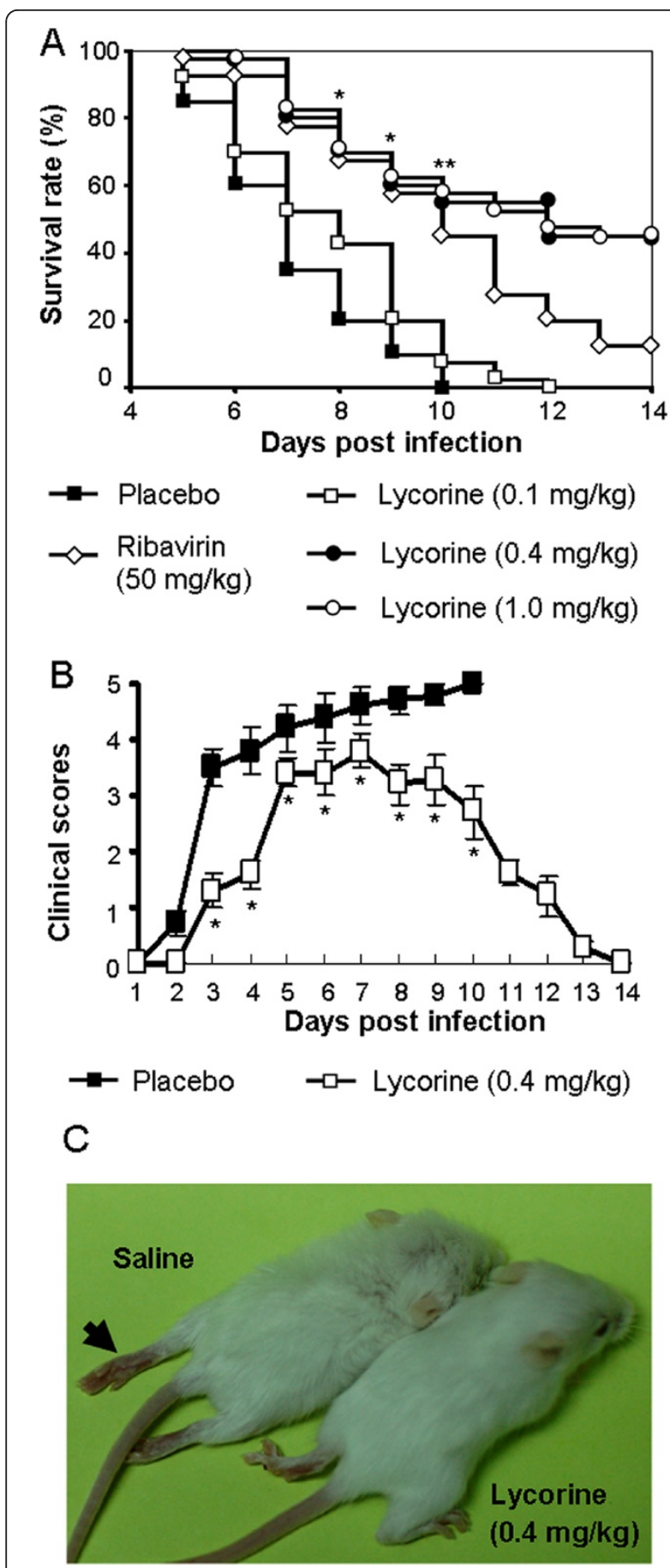

Figure 4 Lycorine treatment reduced the mortality of EV71infected mice. A, survival rates of the EV71 infected mice treated with placebo, ribavirin and lycorine (three different doses) were recorded to $14 \mathrm{dpi}(n=40){ }^{*}: p<0.05{ }^{* *}: p<0.001$ (Survival rate of the mouse after $0.4 \mathrm{mg} / \mathrm{kg}$ lycorine treatment compared to that of the placebo). B, the clinical scores of infected-mice treated with placebo or lycorine $(0.4 \mathrm{mg} / \mathrm{kg})$ was systematically evaluated in an independent experiment $(n=40) .{ }^{*}, p<0.05$. C, photos were a typical phenotype of ruffled hair and paralysis of hind limbs caused by EV71 infection at $8 \mathrm{dpi}$ (left panel, indicated by arrow) and the phenotype was prevented by the lycorine treatment (right panel).
This result revealed that $0.4 \mathrm{mg} / \mathrm{kg}$ was a proper dosage and this dosage was used to analysis the effect of lycorine against EV71 in the further experiments.

The clinical scores of infected mice treated with placebo or lycorine $(0.4 \mathrm{mg} / \mathrm{kg})$ were systematically evaluated. Treatment with lycorine delayed the paralysis appearance to 1 day later compared with that of the placebo. And the surviving mice (45\%) in the lycorine group were completely recovered within $14 \mathrm{dpi}$ (Figure $4 \mathrm{~B}$ and $4 \mathrm{C}$ ), while all of the mice in the placebo group were died within $10 \mathrm{dpi}$. Consistent with the results of the clinical scores and survival rates, virus replication in the muscle of lycorine-treated mice were inhibited by 10-100 folds at different time points compared to that of the saline control as detected by qRT-PCR and semi-quantitative RTPCR (Figure 5A and 5B). Lycorine treatment also obviously reduced the amount of virions in muscle tissues compared to the saline control by immunohistological staining (Figure 6A). In the saline-treated group, serious muscle necrotic appeared at $3 \mathrm{dpi}$ and lead to paralysis of mice, while the lycorine-treatment $(0.4 \mathrm{mg} /$ $\mathrm{kg}$ ) obviously reduced the muscle damage caused by EV71 infection (Figure 6B, moderate inflammation were observed in the muscle tissues of lycorine treated mice at $3 \mathrm{dpi}$ and $9 \mathrm{dpi}$, contrast to the necrotising myositis of placebo-treated mice from 3 dpi to $9 \mathrm{dpi}$ ).

\section{Lycorine treatment protected mice from apparent symptoms post non-lethal dose EV71 challenge}

The mouse model with lethal-dose EV71 infection was used to imitate the severe complications of EV71 infected patients. However, as most of the EV71 infection in patients leads to symptoms resolves spontaneously [13], we also explored the effect of lycorine against a moderate dose of MP10 infection in mice, which was supposed to imitate the self limited patients. The virus replication in muscle tissues of lycorine-treated $(0.4 \mathrm{mg} / \mathrm{kg})$ mice was significantly inhibited by more than 100 -fold compared to the saline control as detected by qRT-PCR and semiquantitative RT-PCR (Figure 7A and 7B). The salinetreated mice developed transient ruffled hair and paralysis and recovered within 8 days. The lycorine treatment protected the infected-mice from symptoms of paralysis except occasionally skin fur (Figure 7C and 7D). These results indicated that lycorine treatment was able to completely protect the mice from obviously symptoms upon a low-dose EV71 challenge.

\section{Discussion}

Along with its broad biological activities and capacity to inhibit the replication of many different viruses, we confirmed that lycorine can inhibit EV71 infection. Lycorine showed inhibitory activity against EV71 replication in RD cells, and lycorine treatment significantly enhanced 


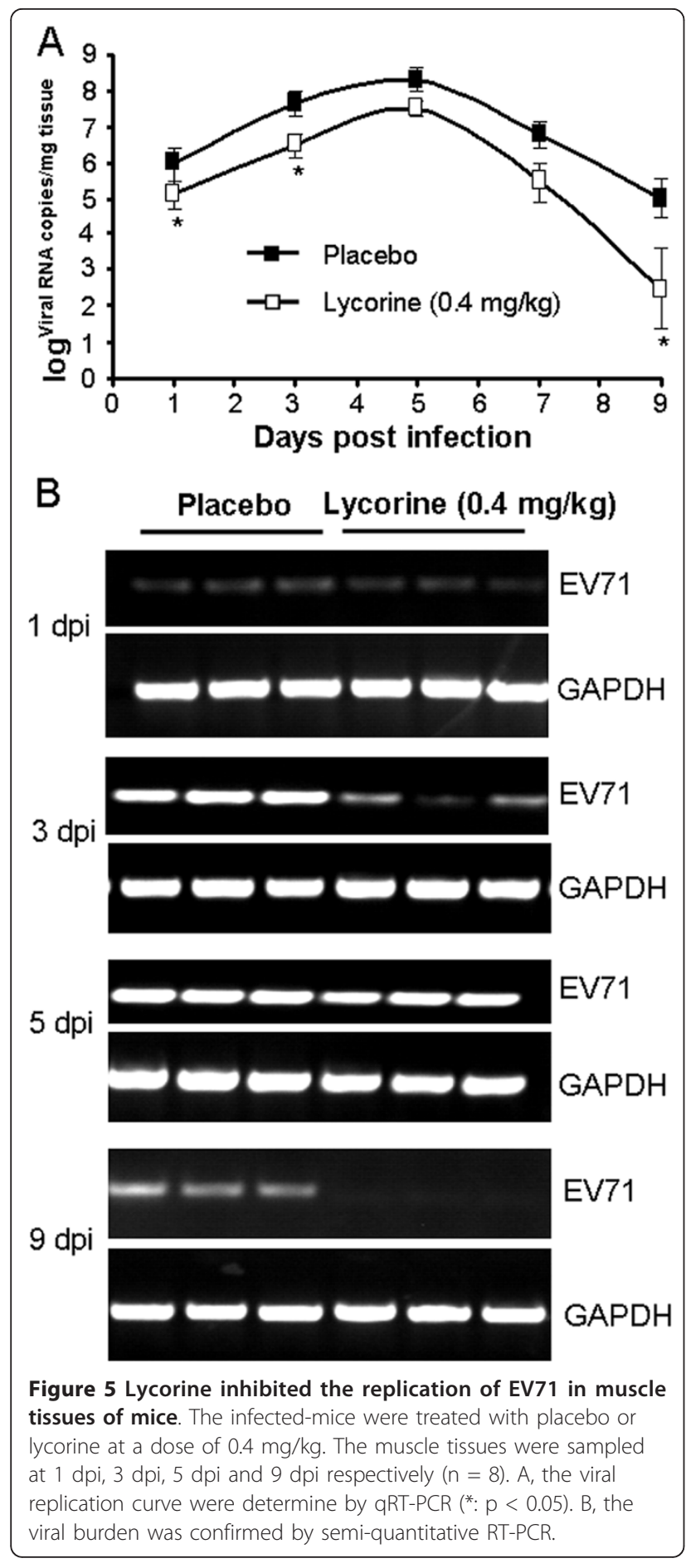

the survival rate of EV71-infected mice, which demonstrates that lycorine may be a potential drug candidate for the clinical treatment of EV71 infection-induced diseases.

Previous studies indicated that lycorine can inhibit protein synthesis in eukaryotic cells $[30,31]$ and in cellfree systems in which protein synthesis is catalysed by eukaryotic ribosomes [32]. However, there have debates on which step of protein synthesis is blocked by lycorine. Jimenez et al. has indicated that lycorine halts protein synthesis in eukaryotic cells by blocking the peptide bond formation [31]. Lycorine was shown to prevent the coupling of the $\mathrm{N}$-acetyl leucyl residue from UACCAacetyl leucine to puromycin, and it was therefore postulated that these compounds inhibited the transpeptidation reaction [32]. In contrast, it has been reported that lycorine affects the termination but not the elongation nor the cleavage of the polyprotein [33]. The single large coding region of the EV71 genome is flanked by 5 ' and 3' untranslated regions (5' and 3' UTR). The coding region is translated as a single polyprotein, which is then processed by viral proteases to yield mature viral proteins including the capsid proteins (VP1-VP4) and non-structural proteins (2A-2C and 3A-3D) [34]. We investigated the inhibitory mechanism of lycorine on EV71 replication by detecting the step of the viral life cycle that was initially blocked post drug treatment and found that the repression effect of lycorine on the synthesis of viral proteins located at $\mathrm{C}$ terminal of the polyprotein was earlier and more substantial than its effect on viral proteins located at $\mathrm{N}$ terminal of polyprotein (Figure 3); therefore, we concluded that the drug inhibits the elongation of the viral polyprotein during protein synthesis. The imbalanced synthesis of viral proteins could interrupt the package of the virus. And the inhibition of 3D protein could result in the reduction of replication of virus, as the $3 \mathrm{D}$ protein is the RNA polymerase of EV71 [35].

In contrast to its other wide range of biological effects, lycorine is suspected to be the source of Amaryllidaceae poisoning in humans and animals [36]. Empirical data from previous reports suggests that lycorine may be responsible for symptoms such as nausea and emesis [22]. High concentration of lycorine-induced apoptosis of RD cells was observed in this study (Figure 2), which indicated that lycorine is noxious to eukaryotic cells. However, lycorine could inhibit the replication of EV71 at very low concentration and the $\mathrm{IC}_{50}$ for inhibiting EV71 infection was approximately 100 -fold lower than the $\mathrm{CC}_{50}$ on $\mathrm{RD}$ cell, suggesting that it had potential application in the clinical treatment of EV71 infection. This assumption was verified by evaluating the antiviral effect of lycorine in a mouse model, as the survival rate of $0.4 \mathrm{mg} / \mathrm{kg}$ lycorine-treated mice was significantly enhanced compared to the control mice upon lethal EV71 infection (Figure 4A), and the alleviation of acute symptoms and reduction of pathological changes in the muscles of lycorine-treated mice were achieved by inhibiting the replication of virus (Figure 4, 5, 6). The surviving mice in the lycorine treated group recovered within 14 days. Furthermore, lycorine treatment did not cause 


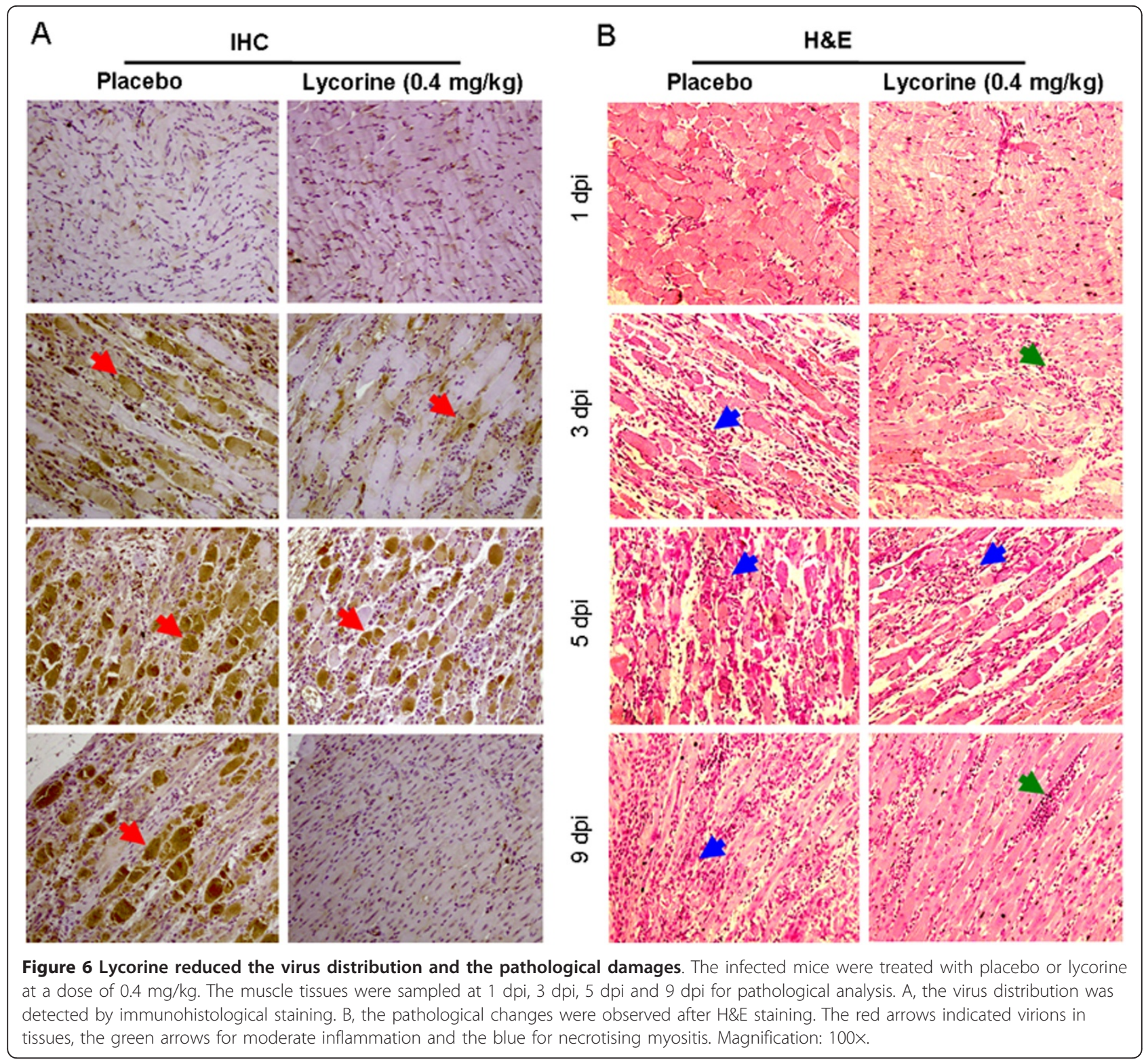

any obvious side effects in the mice at the tested doses (data not shown).

Following lethal EV71 infection, the lycorine-treated mice had a survival rate that reached $45 \%$, while all of the saline-treated mice were died within 14 dpi (Figure 4). In previous studies, treatment with several drug candidates, including ribavirin, bovine lactoferrin, siRNA and type I interferon, were able to enhance the survival rates of infected mice to $18 \%-100 \%$ [14-17]. However, because the infection doses of virus and strains were different in these experiments, it is difficult to compare the activity of these drugs, but we observed that the efficiency of lycorine against EV71 infection was better than ribavirin, as shown in $\mathrm{IC}_{50}$ determination (Figure $1 \mathrm{~A}$ ) and evaluation by a mouse model (Figure $4 \mathrm{~A}$ ).
Furthermore, as most of the EV71 infections were selflimited and did not cause severe complications in patients, self-resolved EV71 infection model, in which the infected mice develop paralysis at $5 \mathrm{dpi}$ and the symptoms were basically self-limited within $8 \mathrm{dpi}$. As we expected, lycorine treatment was able to protect the infected-mice from paralysis symptoms by inhibiting EV71 replication (Figure 7). Meanwhile, we found that lycorine could also inhibit the infectivity of three other EV71 strains (these strains were isolated from clinical specimens from different regions of mainland China and belong to the C4 genotype) on RD cells (data not shown); which demonstrates that lycorine has an effective antiviral spectrum against EV71 strains prevalent in mainland China. 


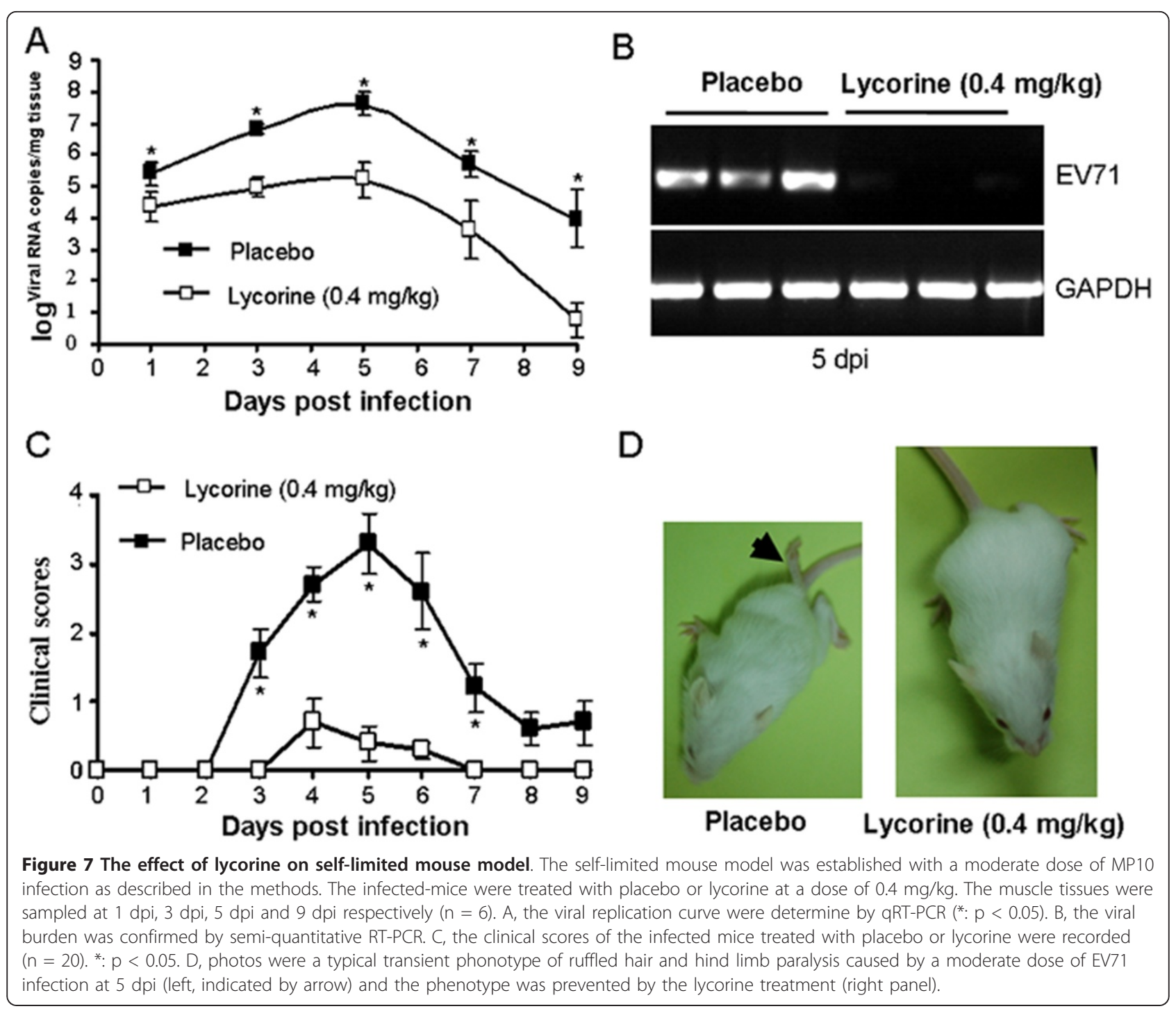

\section{Conclusion}

In summary, we have shown that lycorine is a promising drug candidate for treating EV71 infections that has potential application in the clinical therapy of EV71infected patients and that may contribute to the control of EV71 epidemics in Asia.

\section{Acknowledgements}

This work was supported by the National Natural Science Foundation of China [31000988/C040602], the National Basic Research Program of China [973 Program, 2011CB504903], and the National Science and Technology Major Projects [2011ZX09307-302-03].

\section{Author details}

'Key Laboratory of Human Diseases Comparative Medicine, Ministry of Health; Institute of Laboratory Animal Science, CAMS \& Comparative Medicine Centre, PUMC, Chao Yang Strict, Pan Jia Yuan Nan Li No.5, Beijing 100021, China. ${ }^{2}$ Key Laboratory of Human Diseases Animal Models, State administration of Traditional Chinese Medicine; Institute of Laboratory
Animal Science, CAMS \& Comparative Medicine Centre, PUMC, Chao Yang Strict, Pan Jia Yuan Nan Li No.5, Beijing 100021, China.

\section{Authors' contributions}

$J L$ and $Y Y$ carried out all experiments except for the pathology analysis and draft the manuscript. YX and CM carried out pathology analysis and immunohistochemical staining. CQ participated in the designing of experiment and edited the manuscript. LZ provided overall supervision, financial support and prepared the final version of the manuscript. All authors read and approved the final manuscript.

\section{Competing interests}

The authors declare that they have no competing interests.

Received: 29 June 2011 Accepted: 27 October 2011 Published: 27 October 2011

\section{References}

1. Schmidt NJ, Lennette EH, Ho HH: An apparently new enterovirus isolated from patients with disease of the central nervous system. $J$ Infect Dis 1974, 129:304-309. 
2. Ang LW, Koh BK, Chan KP, Chua LT, James L, Goh KT: Epidemiology and control of hand, foot and mouth disease in Singapore, 2001-2007. Ann Acad Med Singapore 2009, 38:106-112.

3. Chang LY: Enterovirus 71 in Taiwan. Pediatr Neonatol 2008, 49:103-112.

4. Chan LG, Parashar UD, Lye MS, Ong FG, Zaki SR, Alexander JP, Ho KK, Han LL, Pallansch MA, Suleiman AB, et al: Deaths of children during an outbreak of hand, foot, and mouth disease in sarawak, malaysia: clinical and pathological characteristics of the disease. For the Outbreak Study Group. Clin Infect Dis 2000, 31:678-683.

5. Chang LY, Huang LM, Gau SS, Wu YY, Hsia SH, Fan TY, Lin KL, Huang YC, Lu CY, Lin TY: Neurodevelopment and cognition in children after enterovirus 71 infection. N Engl J Med 2007, 356:1226-1234.

6. Chang LY, Lee CY, Kao CL, Fang TY, Lu CY, Lee PI, Huang LM: Hand, foot and mouth disease complicated with central nervous system involvement in Taiwan in 1980-1981. J Formos Med Assoc 2007, 106:173-176.

7. Chang LY, Lin TY, Hsu KH, Huang YC, Lin KL, Hsueh C, Shih SR, Ning HC, Hwang MS, Wang HS, Lee CY: Clinical features and risk factors of pulmonary oedema after enterovirus-71-related hand, foot, and mouth disease. Lancet 1999, 354:1682-1686.

8. Bible JM, Iturriza-Gomara M, Megson B, Brown D, Pantelidis P, Earl P Bendig J, Tong CY: Molecular epidemiology of human enterovirus 71 in the United Kingdom from 1998 to 2006. J Clin Microbiol 2008, 46:3192-3200

9. Enterovirus 71: epidemiology and diagnostics. Zh Mikrobiol Epidemiol Immunobiol 2009, 110-116.

10. Ma E, Chan KC, Cheng P, Wong C, Chuang SK: The enterovirus 71 epidemic in 2008-public health implications for Hong Kong. Int J Infect Dis 14:e775-780.

11. Chang LY, Chang IS, Lu CY, Chiang BL, Lee CY, Chen PJ, Wang JT, Ho HN, Chen DS, Huang LM: Epidemiologic features of Kawasaki disease in Taiwan, 1996-2002. Pediatrics 2004, 114:e678-682.

12. Hosoya M, Kawasaki Y, Sato M, Honzumi K, Kato A, Hiroshima T, Ishiko H, Suzuki H: Genetic diversity of enterovirus 71 associated with hand, foot and mouth disease epidemics in Japan from 1983 to 2003. Pediatr Infect Dis J 2006, 25:691-694.

13. Zhang Y, Tan XJ, Wang HY, Yan DM, Zhu SL, Wang DY, Ji F, Wang XJ, Gao YJ, Chen L, et al: An outbreak of hand, foot, and mouth disease associated with subgenotype C4 of human enterovirus 71 in Shandong, China. J Clin Virol 2009, 44:262-267.

14. Weng TY, Chen LC, Shyu HW, Chen SH, Wang JR, Yu CK, Lei HY, Yeh TM: Lactoferrin inhibits enterovirus 71 infection by binding to VP1 protein and host cells. Antiviral Res 2005, 67:31-37.

15. Li ZH, Li CM, Ling P, Shen FH, Chen SH, Liu CC, Yu CK, Chen SH: Ribavirin reduces mortality in enterovirus 71-infected mice by decreasing viral replication. J Infect Dis 2008, 197:854-857.

16. Sim AC, Luhur A, Tan TM, Chow VT, Poh CL: RNA interference against enterovirus 71 infection. Virology 2005, 341:72-79.

17. Liu ML, Lee YP, Wang YF, Lei HY, Liu CC, Wang SM, Su IJ, Wang JR, Yeh TM, Chen SH, Yu CK: Type I interferons protect mice against enterovirus 71 infection. J Gen Virol 2005, 86:3263-3269.

18. Jaspersen-Schib R: Toxic amaryllidaceas. Pharm Acta Helv 1970, 45:424-433.

19. Lamoral-Theys D, Decaestecker C, Mathieu V, Dubois J, Kornienko A, Kiss R, Evidente A, Pottier L: Lycorine and its derivatives for anticancer drug design. Mini Rev Med Chem 2010, 10:41-50.

20. Cedron JC, Gutierrez D, Flores N, Ravelo AG, Estevez-Braun A: Synthesis and antiplasmodial activity of lycorine derivatives. Bioorg Med Chem 2010, 18:4694-4701.

21. Mikami M, Kitahara M, Kitano M, Ariki Y, Mimaki Y, Sashida Y, Yamazaki M, Yui S: Suppressive activity of lycoricidinol (narciclasine) against cytotoxicity of neutrophil-derived calprotectin, and its suppressive effect on rat adjuvant arthritis model. Biol Pharm Bull 1999, 22:674-678.

22. Kretzing S, Abraham G, Seiwert B, Ungemach FR, Krugel U, Regenthal R: Dose-dependent emetic effects of the Amaryllidaceous alkaloid lycorine in beagle dogs. Toxicon 2011, 57:117-124.

23. leven $M$, van den Berghe DA, Vlietinck AJ: Plant antiviral agents. IV. Influence of lycorine on growth pattern of three animal viruses. Planta Med 1983, 49:109-114.

24. Szlavik L, Gyuris A, Minarovits J, Forgo P, Molnar J, Hohmann J: Alkaloids from Leucojum vernum and antiretroviral activity of Amaryllidaceae alkaloids. Planta Med 2004, 70:871-873.
25. Li SY, Chen C, Zhang HQ, Guo HY, Wang H, Wang L, Zhang X, Hua SN, $Y u$ J, Xiao PG, et al: Identification of natural compounds with antiviral activities against SARS-associated coronavirus. Antiviral Res 2005, 67:18-23.

26. Liu JN, Wang W, Duo JY, Hao Y, Ma CM, Li WB, Lin SZ, Gao XZ, Liu XL, $\mathrm{Xu} Y \mathrm{~F}$, et al: Combined peptides of human enterovirus 71 protect against virus infection in mice. Vaccine 2010, 28:7444-7451.

27. Reed $L \mathrm{M}$, Muench $\mathrm{H}$ : A simple method of estimating fifty percent endpoints. Am J Hyg 1938, 27:493-497.

28. Massignan T, Stewart RS, Biasini E, Solomon $I H$, Bonetto $V$, Chiesa R, Harris DA: A novel, drug-based, cellular assay for the activity of neurotoxic mutants of the prion protein. J Biol Chem 2010, 285:7752-7765.

29. Jia CS, Liu JN, Li WB, Ma CM, Lin SZ, Hao Y, Gao XZ, Liu XL, Xu YF, Zhang LF, Qin C: The cross-reactivity of the enterovirus 71 to human brain tissue and identification of the cross-reactivity related fragments. Virol J 2010, 7:47.

30. Jimenez ALS, Vazquez D: Yeast ribosomal sensitivity and resistance to the AMARYLLIDA ALKALOIDS. FEBS Letters 1975, 60:66-70.

31. Jimenez A, Santos A, Alonso G, Vazquez D: Inhibitors of protein synthesis in eukarytic cells. Comparative effects of some amaryllidaceae alkaloids. Biochim Biophys Acta 1976, 425:342-348.

32. Kukhanova M, Victorova L, Krayevsky A: Peptidyltransferase center of ribosomes. On the mechanism of action of alkaloid lycorine. FEBS Lett 1983, 160:129-133.

33. Rombaut $B$, Vrijsen $R$, Delgadillo $R$, Vanden Berghe $D$, Boeye A: Characterization and assembly of poliovirus-related $45 \mathrm{~S}$ particles. Virology 1985, 146:111-119.

34. Brown BA, Pallansch MA: Complete nucleotide sequence of enterovirus 71 is distinct from poliovirus. Virus Res 1995, 39:195-205.

35. Jiang $H$, Weng L, Zhang N, Arita M, Li R, Chen L, Toyoda T: Biochemical characterization of enterovirus 71 3D RNA polymerase. Biochim Biophys Acta 2011, 1809:211-219.

36. Mrvos R, Krenzelok EP, Jacobsen TD: Toxidromes associated with the most common plant ingestions. Vet Hum Toxicol 2001, 43:366-369.

doi:10.1186/1743-422X-8-483

Cite this article as: Liu et al.: Lycorine reduces mortality of human enterovirus 71 -infected mice by inhibiting virus replication. Virology Journal 2011 8:483.

\section{Submit your next manuscript to BioMed Central and take full advantage of:}

- Convenient online submission

- Thorough peer review

- No space constraints or color figure charges

- Immediate publication on acceptance

- Inclusion in PubMed, CAS, Scopus and Google Scholar

- Research which is freely available for redistribution

Submit your manuscript at www.biomedcentral.com/submit
C) Biomed Central 